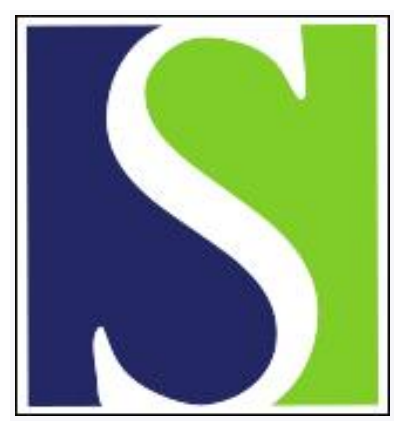

Scand J Work Environ Health 1994;20(2):122-127

https://doi.org/10.5271/sjweh.1422

Issue date: 01 Apr 1994

Associations between organizational factors and safety and contingency measures on offshore petroleum platforms.

by Rundmo T

Affiliation: University of Trondheim, Department of Psychology, Dragvoll, Norway.

This article in PubMed: www.ncbi.nlm.nih.gov/pubmed/8079133

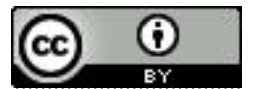




\title{
Associations between organizational factors and safety and contingency measures on offshore petroleum platforms
}

\author{
by Torbjørn Rundmo, $\mathrm{PhD}^{1}$
}

RUNDMO T. Associations between organizational factors and safety and contingency measures on
offshore petroleum platforms. Scand $J$ Work Environ Health 1994;20:122-7.

OBJECTIVEs - The study determined the associations between organizational factors and safety and contingency measures among employees on the Norwegian continental shelf.

METHODs - A self-administered survey among offshore petroleum personnel was conducted in the spring of 1990 . The survey drew respondents from five companies and eight installations. The response rate was $92 \%(\mathrm{~N}=915)$.

Results - Substantial correlations were found between management and employee commitment and involvement in safety work, social support, attitudes towards safety measures, and the personnel's satisfaction-dissatisfaction with the safety and contingency measures.

Conclusions - Employee perceptions of greater management commitment, social support, and subjective evaluations of priorities of safety versus production goals were all important predictor variables for employee satisfaction with safety and contingency measures.

KEY TERMS - accident prevention, management commitment, management involvement, occupational health, social support.

Safety and contingency measures or safety program factors are aimed at directly improving the safety level. Examples of such measures are personal protective equipment, safety training, and safety instructions. Organizational and social factors (ie, factors not primarily directed at improving the safety level) can also affect safety. Examples of such factors are management commitment and involvement in safety work, social support from management, supervisors and other workers, and the personnel's attitudes towards safety measures. Social support is defined as social interaction with persons comprising tangible help, emotional support, and information (1-5). Attitudes towards accident prevention work are reflected in employee perceptions of the priorities of safety versus operational goals and the attribution of accident causes. (See, eg, reference 6.)

Most safety program factors, as well as the aforementioned organizational factors, are important dimensions of the "safety climate" of an enterprise. Safety climate is defined as employee perception of the work environment $(7,8)$. According to Zohar (8), safety climate consists of the following dimen-

I University of Trondheim, Department of Psychology, Dragvoll, Norway.

Reprint requests to: Dr T Rundmo, University of Trondheim, Department of Psychology, N-7055 Dragvoll, Norway. sions: safety training programs, management attitudes towards safety work, effects of safe conduct on promotion and social status, the level of risk at the place of work, priorities of work tempo versus safety, and the status of safety officers and safety committees. Brown \& Holmes (7) reduced the model to a three-factor model consisting of management concerns, management safety activities, and employee risk perception. Dedobbeleer \& Béland (9) tested Brown \& Holmes' safety climate model among workers employed on construction sites. They reduced it to a two-factor model consisting of management commitment (management concern and management safety activities) and worker involvement.

Organizational and social factors affecting safety prevention work must be distinguished from safety and contingency measures. Organizational factors can affect the safety work and therefore also satisfaction-dissatisfaction with the safety and contingency conditions among employees. If so, it is reasonable to expect that organizational factors affect variations in satisfaction-dissatisfaction with safety and contingency factors.

The specific objective of this paper was to determine the effect of organizational and social factors (ie, management and employee commitment and involvement in safety work, social support, and employee attitudes towards safety prevention work) on satisfaction-dissatisfaction with safety and contingency measures on offshore petroleum platforms. 


\section{Subjects and methods}

\section{Sample}

A sample, intended to be representative of the offshore petroleum industry on the Norwegian Continental Shelf, was selected. It was taken from eight platforms and five companies. All personnel present on the platforms at a specific time took part in the survey. Out of those living on the platforms at the time, $92 \%$ replied to the questionnaire $(\mathrm{N}=915)$.

\section{Measures}

In the questionnaire the respondents were asked to assess their satisfaction with the safety and contingency factors on the platform, management and employee commitment, and involvement in safety work, social support from management, supervisors and colleagues, and their own attitudes towards safety measures.

Safety and contingency factors. Safety and contingency aspects included employee evaluation of protective measures, safety instructions, and training. The respondents were asked to rate their own satisfaction-dissatisfaction with the following items: control and inspection in safety work, work instructions, safety instructions, follow-up measures taken after injuries and accidents, first-aid training, contingency training, safety training, order and cleanliness at the place of work, access to emergency exits and escape routes, protection and safety devices on machines and equipment, marking and sign posting, availability of personal protective equipment, and use of personal protective equipment. The evaluation included ratings on a five-point scale for each test item. The scale ranged from "very satisfied" to "very dissatisfied."

Commitment and involvement in safety work. The respondents were asked to rate to what extent they believed that the following people were concerned with their safety and in participating in accident prevention work: platform management, immediate supervisors, trade unions, fellow workers, and the respondent himself (10). For this factor, a five-point rating scale was also applied. The scale ranged from "very concerned" to "not concerned at all" in improving safety and involvement in accident prevention work.

Social support. The perception of instrumental support (ie, aid in the form of changes in the environment), emotional support (ie, feeling of trust and concern), and informal support (ie, advice, suggestions and information) was measured. The respondents were asked the following questions: "How much support do the following people provide you with to manage your work?"; "To what extent can you talk with the following people?"; and "How much do you feel you can trust the following people when things get difficult at your place of work?" They were asked to give separate ratings for supervisors, fellow workers, and trade union representatives in reply to each of the three questions. The five-point scale which was used ranged from "very much support" to "very little support." Social support has been measured in the same way in previously published studies $(1,2)$.

Attitudes towards accident prevention work. Selected items were applied from a questionnaire developed for the evaluation of safety attitudes in industry (6). The following items were included: "sometimes it is necessary to depart from safety requirements for the sake of production"; "good operational economy is often in conflict with measures to improve personal safety"; "rules and instructions relating to personal safety sometimes make it difficult to keep up with production targets"; "sometimes it is necessary to take risks to get a job done"; "whenever I see safety instructions not being complied with, I call attention to it on the spot"; "many minor injuries and minor accidents are an indication that serious accidents can also easily occur"; "safety measures only shift the danger from one area to another"; "occupational accidents are often the result of bad planning and poor management"; "calling attention to breaches of safety can easily be felt as unnecessary hassle"; "good proposals on how to improve safety are often dropped if they cost too much"; and "many accidents just happen, there is little one can do to avoid them." The five-point scale used to measure attitudes, ranged from "agree strongly" to "disagree strongly."

\section{Analysis}

Because of the great number of single items used in the measurement, it was first considered necessary to replace single test items by indices depicting the underlying structure of the evaluations (belief dimensions). To detect the underlying factor, principal component analysis with iteration and varimax rotation, which yields orthogonal factors, was used. Missing values were excluded listwise (ie, all of the cases with missing values for one or more of the items were eliminated). For testing the reliability of the dimensions Cronbach's alpha was used (11).

For each person the scores on the test items belonging to a certain index were then added without differential weighting and a score was determined for each dimension. For testing the differences in sig- 
nificance due to personnel group and employment conditions the chi-square test, t-test, and oneway analysis of variance were used.

The main objective of the study was to predict how management and employee commitment and involvement, attitudes towards safety measures, and social support affected the employee's evaluation of the safety and contingency measures. LISREL (analysis of linear structural relationships) was applied to measure the contribution of these predictors to the endogenous variables (satisfaction-dissatisfaction with the safety and contingency measures) $(12,13)$. The same statistical procedures have previously been described in greater detail in a study of the relations between safety and contingency factors, risk perception, and accidents (14).

LISREL is well suited for estimating relations between latent or unobse ved variables, in which case each has one or more indicators (test items) being measured. The method is also appropriate for analyzing the relations between one or more directly measured endogenous variables and one or more unobserved variables, what is called MIMIC (multiple indicators and multiple causes) models, as well as ordinary path analysis. LISREL was applied to test the MIMIC models.

The maximum likelihood method (LISREL-ML) was used. This method proved to be appropriate for the data. Correlations between the models and the data were examined by means of the chi-square test and tests of general adaptability (goodness-of-fit index) and modified general adaptability (adjusted goodness-of-fit index). The models presented in this paper all satisfied the demand for nonsignificance $(\mathrm{P}>0.10)$.

\section{Results}

Dimensions of the safety and contingency measures

Factor analysis identified the following three dimensions for the safety and contingency measures: protective measures, instruction, and training. Table 1 presents the factor loadings for the test items belonging to each of the dimensions. The eigenvalue was greater than 1.0 for all of the factors. The structure that emerged when all the respondents were included in the analysis was used as an a priori factor structure for each personnel group. The groups were administration and management personnel, production personnel, drilling personnel, maintenance and construction personnel, technical-mechanical personnel, and catering personnel. Reliability was tested separately for each group. As seen in the table, Cronbach's alpha was found to be satisfactory for all of the personnel groups.

\section{Direct evaluations of the safety and contingency measures}

Table 2 shows the percentages "not satisfied" with the three dimensions of the safety and contingency measures in relation to personnel category. The category "not satisfied" contained those who were strongly dissatisfied, dissatisfied, and neutral (15). The table indicates the following: (i) the greatest percentage of persons were "not satisfied" with training (contingency, safety, first-aid), (ii) many were "not satisfied" with work instructions and safety instructions, and (iii) protective measures represented the factor producing the greatest satisfaction.

To test whether the differences in various groups of personnel were significant, a oneway analysis of

Table 1. Dimensions of the safety and contingency measures and reliability of the factors.

\begin{tabular}{|c|c|c|c|c|c|c|c|c|}
\hline \multirow[b]{2}{*}{ Factor } & \multirow[b]{2}{*}{$\begin{array}{l}\text { Factor } \\
\text { loading }\end{array}$} & \multicolumn{7}{|c|}{ Cronbach's alpha } \\
\hline & & Total & $\begin{array}{l}\text { Adminis- } \\
\text { tration and } \\
\text { manage- } \\
\text { ment }\end{array}$ & $\begin{array}{l}\text { Produc- } \\
\text { tion }\end{array}$ & Drilling & $\begin{array}{l}\text { Mainte- } \\
\text { nance and } \\
\text { construc- } \\
\text { tion }\end{array}$ & $\begin{array}{l}\text { Technical- } \\
\text { mechani- } \\
\text { cal }\end{array}$ & Catering \\
\hline \multicolumn{9}{|l|}{ Protective measures } \\
\hline $\begin{array}{l}\text { Availability of personal } \\
\text { protective equipment } \\
\text { Use of personal } \\
\text { protective equipment } \\
\text { Safety devices on } \\
\text { machinery and equipment } \\
\text { Access to emergency } \\
\text { exits } \\
\text { Marking and sign posting } \\
\text { Order and cleanliness }\end{array}$ & $\begin{array}{l}0.76 \\
0.73 \\
0.66 \\
0.65 \\
0.65 \\
0.46\end{array}$ & 0.801 & 0.697 & 0.829 & 0.757 & 0.818 & 0.816 & 0.856 \\
\hline \multicolumn{9}{|l|}{ Instructions } \\
\hline $\begin{array}{l}\text { Work instruments } \\
\text { Control and inspections } \\
\text { Safety instruments } \\
\text { Follow-up measures }\end{array}$ & $\begin{array}{l}0.79 \\
0.77 \\
0.76 \\
0.55\end{array}$ & 0.760 & 0.729 & 0.761 & 0.697 & 0.769 & 0.742 & 0.704 \\
\hline \multicolumn{9}{|l|}{ Training } \\
\hline $\begin{array}{l}\text { Contingency training } \\
\text { First-aid training } \\
\text { Safety training }\end{array}$ & $\begin{array}{l}0.85 \\
0.83 \\
0.76\end{array}$ & 0.753 & 0.839 & 0.886 & 0.817 & 0.844 & 0.792 & 0.896 \\
\hline
\end{tabular}


Table 2. Percentages of workers not satisfied with the safety and contingency measures according to personnel group.

\begin{tabular}{|c|c|c|c|c|c|c|c|c|}
\hline Factor & $\begin{array}{l}\text { Adminis- } \\
\text { tration } \\
\text { and man- } \\
\text { agement }\end{array}$ & $\begin{array}{l}\text { Produc- } \\
\text { tion }\end{array}$ & Drilling & $\begin{array}{l}\text { Mainte- } \\
\text { nance } \\
\text { and con- } \\
\text { struction }\end{array}$ & $\begin{array}{l}\text { Technical- } \\
\text { mechani- } \\
\text { cal }\end{array}$ & Catering & F-value & P-value \\
\hline \multicolumn{9}{|l|}{ Protective measures } \\
\hline $\begin{array}{l}\text { Availability of personal } \\
\text { protective equipment } \\
\text { Use of personal }\end{array}$ & 4 & 13 & 14 & 21 & 14 & 26 & & \\
\hline $\begin{array}{l}\text { protective equipment } \\
\text { Safety devices on }\end{array}$ & 19 & 22 & 18 & 18 & 19 & 21 & & \\
\hline $\begin{array}{l}\text { machinery and equipment } \\
\text { Access to emergency }\end{array}$ & 36 & 24 & 26 & 31 & 27 & 40 & & \\
\hline $\begin{array}{l}\text { exits } \\
\text { Marking and sign posting }\end{array}$ & $\begin{array}{l}17 \\
24\end{array}$ & $\begin{array}{l}27 \\
38\end{array}$ & $\begin{array}{l}11 \\
11\end{array}$ & $\begin{array}{l}24 \\
24\end{array}$ & $\begin{array}{l}23 \\
29\end{array}$ & $\begin{array}{l}24 \\
14\end{array}$ & & \\
\hline Order and cleanliness & 15 & 30 & 24 & 27 & 27 & 11 & 1.82 & 0.10 \\
\hline \multicolumn{9}{|l|}{ Instructions } \\
\hline $\begin{array}{l}\text { Work instruments } \\
\text { Control and inspections } \\
\text { Safety instruments } \\
\text { Follow-up measures }\end{array}$ & $\begin{array}{l}31 \\
31 \\
17 \\
23\end{array}$ & $\begin{array}{l}40 \\
36 \\
26 \\
33\end{array}$ & $\begin{array}{l}38 \\
28 \\
28 \\
29\end{array}$ & $\begin{array}{l}32 \\
37 \\
25 \\
40\end{array}$ & $\begin{array}{l}42 \\
33 \\
32 \\
39\end{array}$ & $\begin{array}{l}25 \\
32 \\
21 \\
33\end{array}$ & 2.11 & 0.06 \\
\hline \multicolumn{9}{|l|}{ Training } \\
\hline $\begin{array}{l}\text { Contingency training } \\
\text { First-aid training } \\
\text { Safety training }\end{array}$ & $\begin{array}{l}44 \\
34 \\
34\end{array}$ & $\begin{array}{l}42 \\
39 \\
38\end{array}$ & $\begin{array}{l}56 \\
61 \\
35\end{array}$ & $\begin{array}{l}56 \\
50 \\
43\end{array}$ & $\begin{array}{l}41 \\
36 \\
39\end{array}$ & $\begin{array}{l}44 \\
29 \\
35\end{array}$ & 5.10 & 0.0001 \\
\hline
\end{tabular}

variance was used. Significant differences were found between the groups for instruction and training, but not for protective measures.

\section{Organizational and social factors affecting satisfaction-dissatisfaction with the safety and contingency measures}

The next step was to determine the contribution of (i) management and employee commitment and involvement in safety work, (ii) attitudes towards preventive measures, and (iii) social support to satisfaction-dissatisfaction with the safety and contingency measures. In order to find efficient preventive measures, knowledge was needed about the way these factors affected the personnel's evaluation of the dependent factors.

The reliability of the dimensions commitment and involvement in safety work was found to be at a satisfactory level. Cronbach's alpha was 0.825 . The same was true for social support, for which Cronbach's alpha was 0.855 .

Factor analysis detected the following two dimensions of attitudes towards safety work: (i) priorities of safety versus production goals and (ii) attribution of accident causes. Table 3 on page 126 presents the factor loadings for each of the test items. The reliability of the factors was tested separately for each personnel group. As seen in the table, Cronbach's alpha was found to be satisfactory for each group for the respondents' priority of safety versus production goals. Due to lack of reliability, the attribution of accident causes was excluded from further analyses.

LISREL was used to estimate the correlations between the variables. The model presented in figure 1 consists of a single unobserved endogenous latent variable (safety and contingency measures) measured by three $Y$ variables $\left(Y \simeq y_{1}, y_{2}, y_{3}\right.$ ) (where $y_{1}$ was protective measures, $y_{2}$ was instructions, and $y_{3}$ was training, as shown in the figure). The exogenous var-

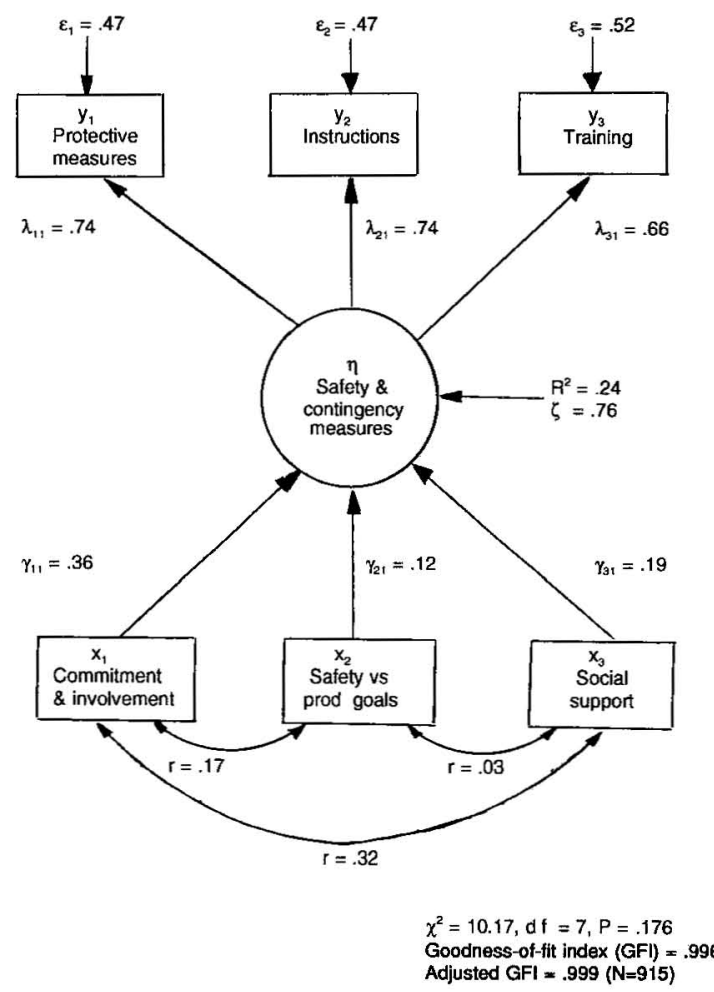

Figure 1. Effects of commitment and involvement, safety versus (vs) production (prod) goals and social support on satisfaction-dissatisfaction with the safety and contingency measures. (df $=$ degrees of freedom, $r=$ correlation coefficient. 
Table 3. Dimensions of the attitudes towards safety work and the reliability of the factors.

\begin{tabular}{|c|c|c|c|c|c|c|c|c|}
\hline \multirow[b]{2}{*}{ Factor } & \multirow[b]{2}{*}{$\begin{array}{l}\text { Factor } \\
\text { loading }\end{array}$} & \multicolumn{7}{|c|}{ Cronbach's alpha } \\
\hline & & Total & $\begin{array}{c}\text { Adminis- } \\
\text { tration and } \\
\text { manage- } \\
\text { ment }\end{array}$ & $\begin{array}{l}\text { Produc- } \\
\text { tion }\end{array}$ & Drilling & $\begin{array}{c}\text { Mainte- } \\
\text { nance and } \\
\text { construc- } \\
\text { tion }\end{array}$ & $\begin{array}{c}\text { Technical- } \\
\text { mechani- } \\
\text { cal }\end{array}$ & Catering \\
\hline \multicolumn{9}{|l|}{$\begin{array}{l}\text { Safety versus operational } \\
\text { goals }\end{array}$} \\
\hline $\begin{array}{l}\text { Sometimes it is necessary } \\
\text { to take risks to get } \\
\text { a job done } \\
\text { Sometimes it is necessary } \\
\text { to depart from safety } \\
\text { requirements for the sake } \\
\text { of production } \\
\text { Good operational economy } \\
\text { is often in conflict } \\
\text { with measures to improve } \\
\text { personnel safety } \\
\text { Rules and instructions } \\
\text { relating to personal } \\
\text { safety sometimes make it } \\
\text { difficult to keep up with } \\
\text { production targets } \\
\text { Safety measures only shift } \\
\text { the danger from one area } \\
\text { to another } \\
\text { Calling attention to } \\
\text { breaches of safety can } \\
\text { easily be felt as } \\
\text { unnecessary hassle } \\
\text { Many accidents just } \\
\text { happen, there is little } \\
\text { to do to avoid them } \\
\text { Whenever I see safety } \\
\text { instructions not being } \\
\text { complied with, I call } \\
\text { attention to it on the spot }\end{array}$ & $\begin{array}{l}0.61 \\
0.61\end{array}$ & 0.732 & 0.696 & 0.708 & 0.736 & 0.695 & 0.733 & 0.746 \\
\hline \multicolumn{9}{|l|}{ Attribution } \\
\hline $\begin{array}{l}\text { Occupational accidents } \\
\text { are often the result of } \\
\text { bad planning and poor } \\
\text { management } \\
\text { Many minor damages and } \\
\text { minor accidents are an } \\
\text { indication that serious } \\
\text { accidents can also easily } \\
\text { occur } \\
\text { Good proposals on how } \\
\text { to improve safety are } \\
\text { often dropped if they cost } \\
\text { too much }\end{array}$ & 0.66 & 0.389 & 0.199 & 0.307 & 0.452 & 0.427 & 0.417 & 0.307 \\
\hline
\end{tabular}

Table 4. Factors affecting satisfaction-dissatisfaction with the safety and contingency measures.

\begin{tabular}{|c|c|c|c|c|c|c|c|}
\hline Predictors & $\mathrm{R}^{2}$ & $\begin{array}{l}\text { Commitment } \\
\text { and invole- } \\
\text { ment } \\
\left(x^{1}\right)\end{array}$ & $\begin{array}{l}\text { Safety } \\
\text { versus } \\
\text { production } \\
\text { goals } \\
\left(x^{2}\right)\end{array}$ & $\begin{array}{l}\text { Social } \\
\text { support } \\
\left(x^{3}\right)\end{array}$ & $\chi^{2}$ & P-value & $N$ \\
\hline \multicolumn{8}{|l|}{ Personnel group } \\
\hline $\begin{array}{l}\text { Maintenance and construction } \\
\text { Management and production } \\
\text { Drilling } \\
\text { Catering } \\
\text { Technical mechanical }\end{array}$ & $\begin{array}{l}0.30 \\
0.27 \\
0.25 \\
0.33 \\
0.13\end{array}$ & $\begin{array}{l}0.39 \\
0.40 \\
0.30 \\
0.62 \\
0.27\end{array}$ & $\begin{array}{r}0.07 \\
0.19 \\
0.13 \\
-0.21 \\
0.10\end{array}$ & $\begin{array}{r}0.25 \\
0.11 \\
0.29 \\
-0.03 \\
0.12\end{array}$ & $\begin{array}{r}5.22 \\
10.83 \\
8.96 \\
5.17 \\
5.10\end{array}$ & $\begin{array}{l}0.633 \\
0.146 \\
0.256 \\
0.639 \\
0.648\end{array}$ & $\begin{array}{r}274 \\
288 \\
81 \\
95 \\
87\end{array}$ \\
\hline \multicolumn{8}{|l|}{ Employment condition } \\
\hline $\begin{array}{l}\text { Operator personnel } \\
\text { Contractor personnel }\end{array}$ & $\begin{array}{l}0.25 \\
0.24\end{array}$ & $\begin{array}{l}0.35 \\
0.36\end{array}$ & $\begin{array}{l}0.16 \\
0.08\end{array}$ & $\begin{array}{l}0.20 \\
0.20\end{array}$ & $\begin{array}{l}4.73 \\
6.87\end{array}$ & $\begin{array}{l}0.712 \\
0.443\end{array}$ & $\begin{array}{l}463 \\
399\end{array}$ \\
\hline
\end{tabular}


iables were directly measured by three $\mathrm{x}$ variables $\left(X \simeq x_{1}, x_{2}, x_{3}\right)$, which affect $\eta$ directly, $(X=\xi)$. (The $\mathrm{X}$ variables were commitment and involvement in safety work, priority of safety versus production goals, and social support). Single test items were replaced by indices in the model.

The analysis revealed that management and employee commitment and involvement in safety work, attitudes towards safety measures, and social support contributed significantly to satisfaction-dissatisfaction with the safety and contingency measures [coefficient of determination $\left.\left(R^{2}\right)=0.24\right]$. Contributions from the three exogenous factors, $x_{1}, x_{2}, x_{3}$, were $\mathrm{R}^{2} \times 100$ (ie, 24\%). In addition it was found that $\mathrm{x}_{1}$, management and employee commitment and involvement, was the exogenous factor contributing most to satisfaction-dissatisfaction $\left(\gamma_{11}=0.36\right)$. Priority of safety versus production goals and social support also contributed significantly. Finally the correlation between commitment and involvement and social support was 0.32 . There was also a substantial correlation between commitment and involvement and priority of safety versus production goals.

Next, separate analyses were conducted for each personnel group, as well as for each of the employment conditions, and the effects on the endogenous factor were compared. Seven analyses were carried out. (See table 4.) The results can be summarized as follows: (i) the model (figure 1) was found to be suitable for the data under all of the specified conditions and it satisfied the demand for nonsignificance in all the data sets; (ii) the model was the most successful in explaining satisfaction-dissatisfaction for catering personnel $\left(R^{2}=0.33\right)$, for maintenance and construction personnel $\left(R^{2}=0.30\right)$, and for drillers $\left(R^{2}=0.27\right)$ but was not so successful in explaining the evaluation among technical-mechanical personnel $\left(\mathrm{R}^{2}=\right.$ 0.13 ); (iii) management and employee commitment and involvement was the most important predictor.

\section{Discussion}

The personnel's assessments of management and employee commitment and involvement in safety work, attitudes towards accident prevention, and social support correlated significantly with their satisfaction-dissatisfaction with the safety and contingency factors. The areas which had the strongest effects were (i) commitment and involvement in safety work by supervisors and management (overall this factor had the most important effect on the evaluation of safety and contingency measures) (ii) social support (management and supervisor support were particularly singled out as important); and (iii) attitudes towards accident prevention work (attitudes provided a smaller contribution than the other two dimensions with regard to variation in satisfaction-dissatisfaction with safety and contingency measures).
The most efficient way to reduce dissatisfaction with the safety and contingency factors lies probably in steps aimed directly at improving work and safety instructions, training and safety devices, and steps to improve organizational factors affecting safety and contingency measures (ie, management and supervisor commitment and involvement). Social support and attitudes towards accident prevention work also contributed considerably to the variations in satisfaction-dissatisfaction. In addition, substantial correlations were found between management and supervisor commitment and involvement and social support. Efforts should therefore be directed at improving management and supervisor commitment and involvements and social support.

\section{References}

1. Caplan RD, Cobb S, French JRP, Harrison R, Pinneau SR. Job demands and worker health: main effects of occupational differences. Washington, DC: Department of Health, Education and Welfare, 1975. (HEW publication; NIOSH no 75-160.)

2. Eide R, Hellesøy OH, Gogstad AC. The impact of social support on health. In: Hellesøy OH, ed. Work environment Statfjord field: work environment, health and safety on a North Sea oil platform. Oslo: Universitetsforlaget, 1985:325-40.

3. French JRP, Rogers W, Cobb S. Adjustment as person-environment fit. In: Coello DA, Hamburg DA, Adams JE, ed. Coping and adaption. New York, NY: Basic Books, 1974:97-106

4. House JS. Work stress and social support. New York, NY: Addison Wesley, 1981.

5. Ilstad S. Sosial støtte, påkjenninger og helse [Social support, strain and health]. Tidsskr Nor Psykol 1981; 18:323-30.

6. Rundmo T, Sten T. Holdninger til Sikkerhet. Vurdering av en sikkerhetskampanjes virkninger [Safety attitudes: evaluation of a safety campaign]. Trondheim: Foundation of Scientific and Industrial Research, 1987. (SINTEF-report; STF75 F87039.)

7. Brown RL, Holmes $\mathrm{H}$. The use of a factor-analytic procedure for assessing the validity of an employee safety climate model. Accid Anal Prev 1986;18:44570.

8. Zohar D. Safety climate in industrial organizations: theoretical and applied implications. J Appl Psychol 1980;65:96-101.

9. Dedobbeleer N, Béland. A safety climate measure for construction sites. J Saf Res 1991;22:97-103.

10. Petersen D. The effectiveness of safety programs as perceived by employees. ASSE J 1973;18:22-6.

11. Norusis MJ. SPSS/PC+: advanced statistics. Chicago, IL: SPSS Inc, 1988.

12. Jöreskog KG, Sörbom D. Advances in factor analysis and structural equation models. Cambridge, MA: Abt Books, 1979.

13. Jöreskog KG, Sörbom D. LISREL 7: users' reference guide. Moresville, IN: Scientific Software Inc, 1989.

14. Rundmo T. Risk perception and safety on offshore petroleum platforms - part II: perceived risk, job stress and accidents. Saf Sci 1992;15:53-68.

15. Marek J, Iversen E, Hellesøy OH. Experience of risk and safety. In: Hellesøy $\mathrm{OH}$, ed. Work environment Statfjord field: work environment, health and safety on a North Sea oil platform. Oslo: Universitetsforlaget, 1985:142-74.

Received for publication: 2 July 1993 